\title{
Estimating Probability of Return on Loss and Its Effect on Future Abnormal Return in Iran
}

\author{
Mahmoud Lari Dashtbayaz ${ }^{1}$, Mahdi Salehi ${ }^{1} \&$ Mohammad Hossein Zolfaghar Arani ${ }^{1}$ \\ ${ }^{1}$ Ferdowsi University of Mashhad, Mashhad, Iran \\ Correspondence: Mahdi Salehi, Ferdowsi University of Mashhad, Mashhad, Iran. E-mail: Mehdi.salehi@fum.ac
}

Received: May 3, 2015 Accepted: June 7, 2015 Online Published: June 13, 2015

doi:10.5539/ass.v11n16p320 URL: http://dx.doi.org/10.5539/ass.v11n16p320

\begin{abstract}
The present study aims at investigating, at first, the relationship between the features of loss-making companies and the probability of achieving the first profit in the years following the loss; and then, analyzing the relationship between probable profitability of the loss-making companies and future abnormal return on shares. This study is carried out according to the information available on the companies listed on Tehran Stock Exchange, during 2002-2011, on a selected sample consisting of 72 companies. The method used for hypotheses testing is logistic regression and generalized regression model (linear mixed model). The results obtained from hypotheses testing for return on loss model in this study indicate the existence of a significant positive relationship between the level of the loss-making companies' investment in capital assets and the probability of return on loss; the existence of a significant negative relationship between accounting conservatism level and the probability of profitability; as well as lack of relationship between special expenses ( $\mathrm{R} \& \mathrm{D}$, sales promotion, inventions and discoveries) and the probability of return on loss. The results from the final model test show the significant positive relationship between the probability of return on loss and abnormal return on shares of the companies. The main limitation of the current study is the lack of proper disclosure of some of the variables of this study by firms, including investing in specific costs in financial statements and notes as separate and distinct costs from other expenditures.
\end{abstract}

Keywords: probability of return on loss, conservatism, special expenses, R \& D expense, abnormal return on shares, capital expenditure

\section{Introduction}

Profitability of the companies is one of the most important factors in investment; therefore, the profit forecast by investors has great importance. Investors and creditors expect the performance of companies that they have invested in them meet their expectations, and proceed based on their evaluation of companies' performance according to the type and size of them. Reduction in product life cycles, increasing the effectiveness of technology on company's operations, reduced profitability, reduced liquidity, the expansion of world trade and so on, increased the volatility in the financial environment. In these circumstances, in order to preserve and increase their capital, investors and creditors are trying to obtain information about the performance of the invested companies and need criteria with which they can evaluate management performance of the companies. Investment in loss firms or investment in firms that are making losses for any reason whether internal-or external organizational reasons, makes investors to pay attention to predictions of the future of these companies. Make use of low-priced stocks when the company is making losses, in case one estimates the future profitability of the company, is good practice that can lead to an increase in wealth. Therefore, in this research we have tried to suggest a model for the probability of achieving the first profit during loss-making cycles that can be implemented in companies listed on the Tehran Stock Exchange. The relationship between profit and stock market value is theoretically obvious, so that by increasing in profit, the stock price increases, and by decreasing in profit, the stock price declines. However, the case is opposite in loss-making companies, so that the relationship between the loss and the market value of shares in loss-making companies is negative, i.e., with increased losses in these companies the stock price decline, and by reducing losses, the stock price increases. According to studies, a loss-making company is a company that experiences a steady decline in revenues, these companies can take some actions in future and become profitable, and become less disturbed financially or operationally (Jahankhany \& Ghorbani, 2005). On the other hand, there is this belief that when loss-making companies invest in long-term projects and plans, it is likely that these costs 
would not lead to profitability in the current cycle. However, through the future cash flows and income earned by the company from these projects and plans, these companies achieve significant profits and the negative relationship between loss and stock market value is minimized. Considering the above, in this study we will attempt at first to investigate the relationship between the characteristics of loss-making companies and the probability of achieving the first profit in the years after the loss, and then try to answer the following questions:

1) Are the characteristics of loss-making companies, such as investment and consumption patterns in specific expenditures or capital expenditures and the degree of accounting conservatism, effective on the possibility of the loss reversal in these companies?

2) Is the loss reversal probability fully reflected in market prices?

Undoubtedly, discovering the relationship between the characteristics of loss-making companies and the likeliness of loss reversal, and the way it is reflected in the stock price is ultimately used as an important factor in capital investors' decisions and it contributes to the efficient allocation of investment.

\section{Theoretical Basis of Loss Reversal}

Accounting profit is often seen as the most important item in financial statements, because it is widely considered as one of the key business performance indicators. Many researches show that profit is one of the most influencing items used in determining the value of the company from the information available in the market. In contrast, Klein and Marquardt (2006) show that the fluctuations of the business cycle and macroeconomic productivity is related to fluctuations in gains and losses, in addition, the growth of loss fluctuations is found in the United States and in the United Kingdom even during the economic boom. The difference between economic boom and an increased incidence of loss shows that a negative income cannot be a good indicator of performance. In this context, understanding how to assess and prioritize loss-making companies creates a challenge in the market-based accounting flow research, in which accounting information is used to explain the value. An understanding upon which we can properly evaluate the performance of loss-making companies, using finance and accounting information provided by them. Among the research conducted in the field of evaluation of loss-making companies, using the models based on the value relevance can be found (e.g., Ohlson, 1995; Feltham \& Ohlson, 1995). Modigliani and Miller (1966) showed that the loss can cause a challenge in relative profitability. Because not only the loss is not necessarily a good indicator of company's performance, but also it reduces the ability to predict the reported earnings for future profitability of the business. In contrast, using a valuation model, Darrough and Ye (2007) report that profit is not a relative value for loss-making companies. Jiang and Stark (2013), show that profitability has a confusing negative correlation with the market value. These two studies suggest that in using the accounting information in valuing firms, two points are worth noting: 1 . The accounting losses, due to the real options, are poor signs of future revenues, and 2. The theories related to real options should be added to valuation models of loss-making companies. Hayn (1995) suggests the "abandonment option hypothesis" that demonstrates that continuing losses may propose the dissolution of the corporation by the shareholders. According Hayn (1995) model, Joos and Plesko (2005) developed a "the loss reversal" model that can be used as an indicator for the possibility of "abandonment option" performance. Based on the above-mentioned model, for the relationship between efficiency and profitability, they found that the reaction rate of profitability is positive for losses that have a high probability of reversal, while the coefficient is negligible for losses that are likely to have lower reversal. Although Joos and Plesko (2005) Showed that the causes and nature of the loss worth considering, even though investors do not homogeneously valuate losses, however, they did not check whether profitable trading strategies can be developed based on loss reversal or not? Lee (2011), based on researches of Joos and Plesko (2005) developed a quarterly prediction model for loss-making companies. He suggested that this model can be used to shape the strategies that create a profit margin of return. In Joos and Plesko studies (2005) and Lee (2011), the models are used in which the firms are required to have a worthy record before being analyzed. Obviously, any focus on annual results (seasonal benefit similar to analysis of Lee (2011) provides a relatively small number of companies for analyses in Iran. As a result, a model that is directly based on the Joos and Plesko (2005), as a tool to analyze financial statements, is very limited in our country, unless adjustments to be made in it to requires less information. After this change, the need to test the effectiveness of the modified models is essential. In addition, according to the findings of Lee (2011), if the modified model is effective in analyzing the loss reversal, the following question naturally arises: Does the information in this model can help investors to make better decisions on portfolio allocation? Richardson et al. (2010) and Lewellen (2010) have evaluated the alternative explanations for the possibility of accounting anomalies. Specifically, they determined that any abnormal return pattern may be explained by potential risks, transaction costs, restrictions on short sales, firm size, and current anomalies. In this context, researchers often use the Fama and MacBeth (1973) regression framework to estimate the relationship between future stock returns and characteristics of the company in interest incremental relative to other 
characteristics of the firm related to increasing reversal associated with the future efficiency. After controlling for a larger number of reversal factors, researchers can argue that the relationship between future returns and interest variable shows that interest variable either is mispriced or is in connection with the systemic risk. Adjusting profit variable from misprice does not mean that there is an effective portfolio strategy, which could be exploited. One needs to consider the commercial limits and investment priorities. For example, smaller security with less volatility has higher transaction costs and greater specific risk, and this property prevents their use of the designed portfolio strategy for taking advantage of opportunities provided by mispriced (Fama \& French, 1996). According to research conducted by Lewellen (2010), there is a need for the knowledge of the entire portfolio of the investor, other business strategies for assessing the incremental costs and the use of an additional predictor variable in the model. Specifically, the transaction costs of a particular strategy can be very different from asking whether this strategy can be used in a profitable manner by an investor who practiced commercial transactions in the past using other strategies and has achieved losses. According to what was mentioned above, on whether the probability of loss reversal generated by our model is fully reflected in the stock market prices of Iran, it is needed to try to make sure on how a business strategy can develop from within the possibilities of loss reversal or other characteristics of firms that have the potential to explain their efficiency of which the risk for the decision-makers is effectively controlled.

\section{Theoretical Basis of Relationship between Loss Reversal and Stock Return}

The relationship between profit and stock market value is theoretically obvious, so that by increasing in profit, the stock price increases, and by decreasing in profit, the stock price declines. However, the case is opposite in loss-making companies, so that the relationship between the loss and the market value of shares in loss-making companies is negative, i.e., with increased losses in these companies the stock price decline, and by reducing losses, the stock price increases. According to studies, a loss-making company is a company that experiences a steady decline in revenues, these companies can take some actions in future and become profitable, and become less disturbed financially or operationally (Jahankhany \& Ghorbani, 2005). As mentioned earlier, the relationship between the loss and the market value of shares in loss-making companies is negative. On the other hand, there is this belief that when loss-making companies invest in long-term projects and plans, it is likely that these costs would not lead to profitability in the current cycle. However, through the future cash flows and income earned by the company from these projects and plans, these companies achieve significant profits and the negative relationship between loss and stock market value is minimized. A general explanation is that all investments affect the investors' perspective of future profitability. Accounting allows investments to be made when there is expected future income (Wu et al., 2010). From the perspective of full market capitalization, while there are investment projects with the efficiency exceeding the cost they need the company will not use the maintained income to finance them, and if the company's revenues remain after financing all the investment opportunities, then the revenue is distributed among investors. However, if investment opportunities are more than company's income, then the company will be forced to release new shares or borrowing.

\section{Analyzing the Relationship between Positive and Negative Earnings and Yields}

According to Ball and Brown definition (1968), if during the announcement of accounting profit the stock price changes, then it indicates the knowledge of accounting profit. Having knowledge in this regard led to a series of investigations in $60 \mathrm{~s}$ that is referred to as the relationship between accounting earnings and stock returns. Therefore, one way to describe the usefulness of accounting earnings could be the existence of correlation (R) between stock returns (price changes) and accounting profit. This concept of accounting earnings is in accordance with the information theory. Ball and Brown study under the title "An empirical evaluation of accounting income numbers" in 1968 became a beginning and a turning point for research in this area, and in fact, their research was the basis of future works. In the mentioned study and afterwards, market efficiency is considered as an obvious assumption. The results of the mentioned investigations indicate that there is a correlation between the changes in stock prices at a specified cycle (for example, a year or quarter) and the direction and amount of unusual interest. With the assumption of market efficiency, the results of these studies are consistence with the hypothesis that accounting earnings reflects the effective variables on stock prices. These results also reflect the fact that the annual or quarterly earnings will also have information for the stock market. The studies mentioned above, despite the results mentioned earlier, were not to test two competing hypotheses, i.e. the hypothesis of no effect of accounting changes on stock price because of the equity market performance (Note 1), and the hypothesis of the effects of accounting changes on stock prices (Note 2) . In fact, as mentioned before, in these investigations, market efficiency is accepted as an assumption and results are interpreted based on the same assumption. The definition of accounting profit benefit based on the relationship between profit and returns (price) of shares is in accordance with theoretical framework statement in America (1976) and the principles of accounting, under the 
title of 'guidance for accounting in Iran' (1999). According to the mentioned statement, the main purpose of accounting and accounting profit is as following: "The main task of financial reporting is to provide information to investors and creditors, in order to assess the risk and potential return of investors." The main objective of financial reporting is to provide again information about the function (managers) of institution through profit and its components. The particular interest to investors, creditors, and other individuals in this information is for evaluation of the likeliness of cash flow into the institute. Their interest in cash flow to the institution and the possibility to create a favorable cash flow is their main reason for their interest is information related to the accounting profit."

\section{Experimental Background and Development of Hypotheses}

\subsection{Studies to Develop Hypotheses about the Loss Reversal Model (The First Three Hypotheses)}

Research on the loss reversal has begun from Hayn study (1995). He in his study examines the relationship between the loss of companies and their temporary stock returns using accounting information published by them, and concluded that the relationship between losses and temporary return of stock, will lead the investors to leave loss-making companies if losses continue. If you expect a company to incur losses for sure, it is obvious that its investors liquidate the company, take the resources out of the company, and invest on profitable projects. Therefore, the continuation of the activities in loss-making companies comes from the views of the investors in which they expect the company to eventually restore and achieve profitability again (Burgstahler \& Dichev, 1997). Therefore, the assessment of the probability of loss reversals for investors can be useful in terms of achieving the decision on how much the losses are and whether to stay with the company would eventually result to achieve gains or not. (Joos \& Plesko, 2005). Sin and Watts (2000), assessed the loss-making companies in Australia and showed that investors of loss-making companies that eventually become profitable, treat the losses as a volatile item. They found that the relationship between the loss and stock returns for those loss-making companies that have experienced high loss reversal is less important. In contrast, the probability of loss reversal for those loss-making companies that benefit from a lower level of this index is very effective for evaluating them. Focus continued on investors' expectations about the instability of losses in loss-making companies with researches of Joos and Plesko (2005) on probability of loss reversal for American loss-making companies. The study, which is the basis of many recent studies on the evaluation of loss-making companies, states that the information extracted from the accounting data related to current and past performance of loss-making companies, is useful for prediction of future loss patterns, growth prospects of dividend payment and for likeliness of loss reversal. They stated that investors study the continuation of losses in loss-making companies and the instability of losses in those companies in different ways. Similar to results in research of Burgstahler and Dichev (1997), Joss and Plesko also showed that investors consider the continuation of losses in loss-making companies against loss instability in those companies in different ways. In series of research on performance evaluation of loss-making companies, Lee (2011) develops a profit prediction model using the parameters studied in the Joos and the Plesko model, and found the evidence that the market cannot clearly distinguish between loss continuation and loss instability. With the use of the variables in Joos and the Plesko model and the considering market conditions (market performance level), he argues that investors can have a correct prediction of loss reversal or loss continuity only when clear information is available in the market. Dhaliwal et al. (2012), along with the parameters available in the research of Joos and the Plesko, make use of new variables such as tax items, and shows that abnormal share returns in future have relationship with tax items in loss-making companies. At the same time, he states that investors ignore the positive signs linked to tax items in the beginning, and describe it as unrelated components when making decisions. At earlier times, Balakrishnan et al. (2010) found evidences about investors who may ignore lower market performance for large loss continuity and the possibility of loss reversal. In general, these findings are because in low levels of market performance, investors do not have the ability to assess the loss stability correctly. Since the possibility of loss reversal is a criterion for the assessment of loss making companies, it consequently contains the concepts related to the valuation of companies and continuity of their activities. There are different accounting parameters linked to the future loss reversal, which creates a connection between these concepts and loss reversal. Klein and Marquardt (2006) showed that accounting conservatism is an important parameter in describing annual loss occurrence. Further, Givoly and Hayn (2000) proposed in their research that as the occurrence of loss increases through the time, the degree of accounting conservatism increases. Similar to the results of these two researches, Balakrishnan et al. (2007) by using the data from Australia showed that loss-making companies are more conservative than profitable ones. The common point in all of the three researches is they express that companies with higher levels of accounting conservatism are more likely to experience loss continuation. In other words, conservatism procedures in accounting, cause acceleration in the identification of future losses, or delay in identification of current profits. On the other hand, Darrough and Ye (2007) pointed out that some loss making 
companies in an information based economy (in the case of high performance in the market) are involved in specific extensive investments such as research and development costs. They found that loss making companies with a high level of the research and development costs are likely to report losses for long period of time. Resources attribution to the specific property and costs such as research and development and extraction of mines to their view is an attribute for the loss continuity in loss making companies. Wu et al. (2010) showed that Australian loss making companies are affected by extensive investment of companies' resources in the mines extraction projects. Popularization of conservative accounting procedures and specific investments activities among loss making companies is of great importance in studying the application of these two parameters for the calculation of possibility of future loss reversal. Garsia et al. (2006) investigated whether value relevance of R\&D documented for loss making firms can be generalized profitable firms. They made use of valuation of the remaining profit pattern and showed that the $\mathrm{R} \& \mathrm{D}$ expenses factor for the profitable firms (loss making firms) is likely negative (positive). This pattern is seen because the dynamic assumption of linear information of remaining profit pattern is more suitable compared to loss making firms. The profits of profitable firms contain information about future profits of research and development activities, while profits of loss making companies lack such information. Empirical evidences confirm their predictions for loss making firms. The results of this research show that research and development costs are positively related to the share prices of loss making firms, and are negatively related to the share prices of profitable firms. For extremely loss making companies, massive investment in research and development will lead to improvement of adjusted determination factor of their pattern. Lewis (2008) through a research pointed out that there are inevitable evidence of United States and United Kingdom that show investment in research and the development is positively related to operations and market performance. This study develops previous studies on research and the development, and introduces operations growth stability and market performance as the result of investment in research and development. Their findings confirm the relation between a high level of research and development and the compatibility with sales growth and gross profit only in cases where the company requires investment in research and development due to industrial context of its activity. The results show that greater R \& D improves stock market, as well. The first two hypotheses of this research are related to the reported investment activities in loss making firms. Some of the loss-making firms extensively invest in specific properties, hoping to achieve a share, in future commercial markets (Darrough \& Ye, 2007). In these firms, the level of loss continuity is highly dependent with this type of resources consumption in specific properties, and dramatically changes with the investment policies of the firm. These companies experience loss continuity in their primary levels of investments cycle. They invest vast resources in assets and certain uses such as research and development and extraction of mines. Generally, the interests of these specific investments are returned during several cycles (Givoly \& Hayn, 2000). In addition, investment in specific properties requires successive basic investments. Before these investments could attain a share in the market, they probably experience stable losses. In contrary, investment expenditures in capital assets related to production and market share can be a sign of future profits. In such cases, loss would reverse to profit in near future. In summary, in order to evaluate the relationship between investment activities and loss reversal in the short time, it is necessary to distinguish between the criteria of primary levels of investment and the secondary levels of investment. Firms report their investment activities related to specific properties such as research and development and extraction of mines in early investment cycles. When these companies become ready to produce and sell these products, it is very probable to invest in capital assets. Regarding what was mentioned above, the first and the second assumptions of this research can be stated as follows:

$\mathrm{H}_{1}$ : The possibility of loss making firms becoming profitable in future cycles has negative correlation with level of investment in the specific property reported by the firms.

$\mathrm{H}_{2}$ : The possibility of loss making firms becoming profitable in future cycles has positive correlation with current investment expenses reported by the firms.

On the other hand, the relation between accounting conservatism and loss reversal is not very clear. To make this clear, it is necessary to provide some concepts of conservatism in accounting. Conservatism is considered as the tendency of accountants to consider high level of attention toward identification of good news (like benefits) compared to bad news (like loss) (Basu, 1997, p. 7). Common conservatism procedures consist of appropriation of specific investment as expenses instead of assets, and choosing accounting methods and procedures that constantly estimate higher depreciations and attribution of probable debts. In other words, accounting conservatism is the index of profit stability (Givoly et al., 2007). conservatism is one of the adjustment covenants governing accounting and financial reporting, in other words, in some cases, conservatism requires that a method become selected and exercised that has the least effect on assets, income, profit and shareholders' equity (codification board of Iran's accounting standards, 2004). In accounting literature, two important characteristics of conservatism 
are explored: one is a bias in presenting book value less than its real market value, which is described by Feltham and Olson (1995). The second is tendency to accelerate the identification of losses and the tendency to procrastinate identification of benefits, which is described by Basu (1997). The study of behaviors in context of positive (benefits) and negative (loss) income regarding accounting conservatism became the center of focus by Penman and Zhang (2000) researches. They defined the quality of profit as the change in conservatism accounting in the company for more than one cycle. Their hypothesis was that the difference between the reported net properties using conservatism accounting and net properties that is reported by means of less conservatism accounting is equal to profit reserve. They found that the degree of conservatism defined as the ratio of profit reserves to the operating assets depends on quality of profit to the change in the degree of conservatism through the time. In the this regard, and in Iran as well, Mohamadzadgan (2006) in a research with the title of (The capability of accrual items reliance with the stability profit and shares price) showed that investors have no precise estimate about accrual items with low reliance, and therefore evaluation error is higher in these items compared to other items. Further, operating, and non-operating assets, which are earned by creating current debts, will have much more reliability, and their stability factor would be higher than the case they resulted from non-current debts or issuing common stock that are measured with low reliability. Ghaemi and others (2010) in a research with the title of 'the effect of conservatism on profit stability and the ratio of price to profit, assumed that profit stability in companies reporting more conservative profit is lower, and the ratio of price to profit in companies reporting more conservative profit is lower. Considering the data of the research that consist of 88 companies during 1999 to 2007, the findings of the research is in accordance with the hypothesis. In other word, profit stability and the ratio of price to profit in companies reporting less conservative profit is lower. The results of this research state that conservative accounting would lead to creation of temporary revenues (revenues with the low stability). This subject is particularly helpful and important for financial statement users who try to predict the profit and future cash flows by means of current cycle profit; therefore, while they notify investors and analyzers to this subject to take investment decisions, they suggest that standard making organizations consider benefits and advantages of conservatism accounting all together. It should be noted that conservatism is a result of more emphasis on reliability of information given to financial statements users rather than relevance of provided information. Dechow and Skinner (2000) express that although this tendency toward conservatism is the result of investors and the creditors' support for increasing performance of conventional goals, this is true on the other hand that providing conservative financial reports would lead to some inappropriate results about evaluation goals. One of these items is a mismatch between incomes and costs and this causes income components to be temporary. Therefore, acquiring conservative accounting methods causes the incomes to be less stable compared to the case where less conservatism is applied. Considering the position of financial reporting in providing relevant and reliable information for the users of financial statements on one hand, and the role of conservatism as one of the characteristics of qualitative financial information, as well as the evidences of spreading conservative accounting, on the other hand, it can be stated that the reduction of conservative effects on benefits that is expected to continue for at least a short period of time is being considered. This subject refers to this important point that the firms with higher levels of conservatism are more likely to experience loss continuity, in other words, it accelerates accounting conservatism procedures or identification of future losses, or delays identification of current profits. In contrast, it is expected that this effect become reversed in long term. Numerous conservatism procedures such as loss management (with the activities such as very extensive temporary discounts) have positive effects on near future benefits in short term, and subsequently lead to reporting profit in the following years. However, as these activities seldom occur, it is expected that conservative criteria have negative relationship with loss reversal, too. According to above- mentioned explanations, the third hypothesis of this research is provided as follows:

$\mathrm{H}_{3}$ : The possibility of the loss making firms to become profitable in future cycles has negative relationship with their level of conservatism.

\subsection{Studies Concerning the Development of Abnormal Stock Return Hypothesis (Hypothesis IV)}

Sin and Watts (2000) assessed the loss-making companies in Australia and showed that investors of loss-making companies that eventually become profitable treat the losses as a volatile item. They found that the relationship between the loss and stock returns for those loss-making companies that have experienced high loss reversal is less important. In contrast, the probability of loss reversal for those loss-making companies that benefit from a lower level of this index is very effective for evaluating them. Collins and Hirbar (2002) examined the negative abnormal relationship between stock prices and earnings using a simple model of capitalization of profits for the companies report losses. They hypothesized and found that involving book value of the shares in determining the value, eliminate the negative correlation. The model also suggests that the pattern of capital gains is not well specified. The negative coefficient of profits for loss making companies is a sign of this misspecification. In 
addition, they provided evidences in this context whether the importance of book value would prevent its role as 1- controlling for the level of differences, 2- A representative for the expected future profits, and 3. A representative for elimination of authority in loss making firms. Their results do not support the assumption that the book value importance in cross-sectional assessment patters would prevent its role as a control for the level of differences. However, the results would prevent by usefulness of book value as a representative for elimination of trading authority of loss making companies. Among the researches performed inside the country and based on the information provided by Tehran Stock Exchange, Pourheydari (2004) provides evidences concerning the relationship between the profitability of firms with negative earnings (loss) with the expectations of investors. His research suggested a new relationship between the ratio of market value to book value (MTB) and the ratio of earning to book value (ETB). The results indicate that if the accounting earnings are negative (loss), the two mentioned ratios are negatively and significantly related to each other. Conversely, in firms with positive earnings (benefit), the two ratios have positive and significant relationship. The conclusion that has been more important than the other results in this study is and is highly noted by others in subsequent studies is that as a positive earnings (profits of the firm) are stable, negative earnings (accounting losses) are also stable, especially for firms with small size and high financial leverage. What was mentioned above indicates the impact of market value to book value variables, size, and financial leverage of the firm on the stability or instability of accounting profit and loss in firms. Therefore, we use these variables as the auxiliary and explanatory variables in the model of abnormal returns. By superposing the results mentioned above, it can be argued that the net loss in investment patterns without growth index, has a negative correlation with the stock market value in loss making firms. However, in investment and complete patterns in which the company's growth indexes are gradually added, the rate of loss has not only increased, but also has become positive. This suggests that when loss making companies invest in long-term plans and projects, the negative correlation between the loss and the value of stock market declines. It is even possible that this reverse and negative relationship becomes a direct and positive relationship. The result obtained is that a negative correlation between the loss and the market value of shares in the loss making companies would be affected by the growth in their long-term investments. As already noted, we will eventually evaluate whether is it possible to implement an investment strategy that reflects the information gathered from the loss reversal model in the market? If investors use all the related information at the time price determination of loss making companies, using the information provided by loss reversal would not be able to calculate high abnormal return. In this case, if investors are less likely to pay attention to all the details and are unable to assess accurately the continuing losses, firms with a higher likelihood of loss reversal may be priced less than their actual value. As a result, stock price may not fully reflect information about the continued loss and this may provide an opportunity for a pricing error. Therefore, on the basis of this study, we explore the following hypothesis:

$\mathrm{H}_{4}$ : Loss reversal probability has a positive relationship with future abnormal return of the firm.

\section{Research Methodology}

In terms of purpose, this research is considered an applied research. The purpose of applied researches is the development of applied knowledge in a specific background, and they emphasis on the most effective measure and the causes are less noticed. The method of performing the research is descriptive-correlation. In descriptive study, without paying attention to the causes of the events, it only deals with and describes the quality and the way the events exist, and in correlation study the purpose is to make it clear whether there a relationship between two or several variables, and if yes, how much and to what size and limit? The present research is considered a longitudinal study because it is performed over 10 years, and since and historical data are used, it can be categorized as post-event research. For collecting the data related to the empirical and test assumptions of the research, the data related to the independent variable of the financial statements audited by firms listed in Tehran stock exchange that are published in Islamic research, development and studies website, official website of Tehran stock exchange and in some cases by using Tehran stock exchange databases (Iran Bourse, Tadbir Pardaz and Rahavard Novin softwares) are collected. Statistical society of this research includes the firms accepted by Tehran stock exchange organization and all of the industries during 2002 to 2011. Sampling in this study, with regards to its topic, removal sampling method is used in which the firms with regards to the restrictions mentioned below are selected among all the firms accepted in Tehran stock exchange and have to meet the following conditions:

1. Through the time mentioned, have regularly published financial statements (are accepted before 2002 in Tehran stock exchange).

2. The firm should have become profitable after loss for at least one time.

It is worth mentioning that with respect to above restrictions, 72 firms will remain that actually represent the real 
statistical population of the study.

\section{The Research Model and Variables}

\subsection{The Model of Loss Reversal Probability Estimation}

In this research, in order to evaluate the parameters effective in possibility of loss reversal, we employed Joos and Plesko (2005) research. These parameters can explain future abnormal returns of stock. The idea behind these investigations is that investors consider the application of such parameters on future profits. In this research, to investigate the relationship between properties of loss making firms and the possibility of loss reversal, we have accepted and developed logistic regression model for proving the first, second and the third hypothesis. The model is described in the following equations:

$$
\begin{aligned}
& \log \left(\frac{P\left(Y_{i, t+1}=1\right)}{1-P\left(Y_{i, t+1}=1\right)}\right)=a_{0}+\alpha_{1} A C C_{i, t}+\alpha_{2} \text { PACC }_{i, t}+\alpha_{3} \text { CFO }_{i, t}+\alpha_{4} \text { PCFO }_{i, t}+\alpha_{5} S G_{i, t} \\
& +\alpha_{6} \text { Size }_{i, t}+\alpha_{7} \text { FirstLoss }_{i, t}+\alpha_{8} \text { DIV V }_{i, t}+\alpha_{9} \text { DivStop }_{i, t}+\alpha_{10} I T E_{i, t}+\alpha_{11} \text { EXRD }_{i, t}+\alpha_{12} C I_{i, t} \\
& +\alpha_{13} C_{-} \text {Score }_{i, t}+\alpha_{14} \text { CNOACC C }_{i, t}+\varepsilon
\end{aligned}
$$

Where the variables used in the above model are described as follows:

$Y_{i, t+1}$ : is a variable index that if the company is loss making in year $\mathrm{t}$ and becomes profitable in year $\mathrm{t}+1$, this variable is equal to one, and if it remains in loss making state, it would be equal to zero,

$A C C_{i, t}$ : Is the sum of accrual items and is calculated as follows:

$\mathrm{ACC}=$ Net profit after tax in the year $\mathrm{t}$-Operating cash flows in the year $\mathrm{t}$,

$P A C C_{i, t}$ : three years average of sum of accrual items including year $t$ and years before.

$C_{i, t}$ : Net Operating cash flows of the firm in the year t.

$\mathrm{PCFO}_{i, t}$ : three years average of net operating cash flows of the firm consisting of year $\mathrm{t}$ and years before it.

$S G_{i, t}$ : This variable represents sale growth rate of the firm in the year $\mathrm{t}$, and is calculated as follows:

$$
S G_{t}=\frac{\left(S_{t}-S_{t-1}\right)}{S_{t}}
$$

Size $_{i, t}$ : Size of the firm in the year $\mathrm{t}$, which in this research we measure it by Ln, sum of the assets and sales of the firm, and calculate it as described in the following:

$$
\operatorname{Size}_{t}=\operatorname{Ln}\left(\frac{S_{t}+T A_{t}}{2}\right)
$$

FirstLoss $\mathrm{i}_{\mathrm{i}, \mathrm{:}}$ : Is an artificial variable and is equal to one if it is the first year of loss in the firm, otherwise it is equal to zero.

DIV or DIVStop, which is the profit payment behavior of the firms, and it has two cases: In the first case if the firm pays out dividends in the loss year it is equal to one, and otherwise zero. In the second case if the firm ceases payment of dividends in loss year, is equal to one, and otherwise it would be equal to zero.

$I T E_{i, t}$ : Is the firm's tax on income in the year $\mathrm{t}$.

capital investments specific in the costs research and the development and the extraction and the exploration and the propaganda in the year $\mathrm{t}$.

$C I_{i, t}:$ Net cash flows from the investment activities in the year $\mathrm{t}$.

CNOACC $_{i, t}$ : Value of items cumulative non-operating accruals of the firm in the year $\mathrm{t}$, and is calculated as follows:

$C N O A C C_{i, t}=$ depreciation + net operating cash flows-net profit after tax

- (change in the cash and the cash equivalent-change in working capital)

C-Score: Express the degree of accounting conservatism in the firm, that the calculation will be discussed in the following paragraphs. 
It is worth mentioning that all the variables used in the above model will be divided by sum of the assets in the end of year $\mathrm{t}-1$, except the degree of conservatism.

\subsection{Analysis Model of Relationship between Loss Reversal and Abnormal Return}

To investigate the relationship between abnormal return of the firms' stocks, and the probability of loss reversal in the above stated model, the regression method suggested by the Jiang (2013) and described in the following is employed:

$$
\begin{aligned}
& \text { MAdjRET }_{i, t+1}=b_{0}+b_{1} L_{\text {Loss }} \operatorname{Rev}_{i, t}+b_{2} \operatorname{Size}_{i, t}+b_{3} B M_{i, t}+b_{4} E P+b_{5} D Y_{i, t} \\
& +b_{6} R D_{i, t}+b_{7} C F_{i, t}+b_{8} L E V_{i, t}+b_{9} P_{i, t}+v_{i, t+1}
\end{aligned}
$$

where: MAdjRET $_{i, t+1}$ represents the abnormal return of the firm, and can be calculated by subtracting the firms return in the year $\mathrm{t}$ from market return in the same year. Loss $\operatorname{Rev}{ }_{i, t+1}$ is the probability of loss reversal which will be calculated in the first model of this research, and the Size $_{i, t}$ is the size of the firm in the year $t$, which in this research we measure it by $\mathrm{Ln}$, sum of the assets and sales of the firm, and calculate it as described in the following:

$$
\text { Size }_{t}=\operatorname{Ln}\left(\frac{S_{t}+T A_{t}}{2}\right)
$$

Where in this equation: $M B_{i, t}$ is the ratio of market value to the book value shareholders equity, $E P_{i, t}$ is the firm's earning per share, $D Y_{i, t}$ is the firms' paid profit in the year t, $R D_{i, t}$ is the research and development expenses of the firm in the year $\mathrm{t}, C F_{i, t}$ is the operating net cash flows of the firm in the year $\mathrm{t}, L E V_{i, t}$ represents financial leverage of the firm in the year $\mathrm{t}$ and $P_{i, t}$ shows the stock price in the year $\mathrm{t}$.

It is worth mentioning that all variables used in the above model are divided by sum of the assets in the end of year $\mathrm{t}-1$.

\section{Research Findings}

\begin{tabular}{|c|c|c|c|c|c|c|}
\hline Variable & Year-firm & Average & Middle & $\begin{array}{l}\text { Standard } \\
\text { deviation }\end{array}$ & $\begin{array}{l}\text { Minimum } \\
\text { value }\end{array}$ & $\begin{array}{l}\text { Maximum } \\
\text { value }\end{array}$ \\
\hline Net Income & 720 & 22582 & 8807.5 & 144478 & -2138400 & 1039555 \\
\hline Firm's Return & 720 & 72.71 & 0.425 & 150.46 & -47.74 & 923.67 \\
\hline $\begin{array}{l}\text { The ratio of market value } \\
\text { to book value }\end{array}$ & 720 & 2.461 & 1.547 & 36.664 & -186.25 & 933.50 \\
\hline Total accruals & 720 & -22372.71 & -3384 & 325730 & -4432313 & 2400441 \\
\hline $\begin{array}{l}\text { Net cash flow from } \\
\text { operating activities }\end{array}$ & 720 & 44954.75 & 13373.50 & 280219.10 & -2293778 & 3528676 \\
\hline Sales growth & 720 & 0.593 & 0.110 & 4.798 & -9.940 & 105.82 \\
\hline Income Tax & 720 & 6314.19 & 173 & 23205.92 & 0.00 & 395404 \\
\hline Specific investment costs & 720 & 20814.32 & 10357 & 38850.01 & 298 & 464630 \\
\hline $\begin{array}{l}\text { Net cash flow from } \\
\text { investing activities }\end{array}$ & 720 & -20059.29 & -4270 & 104755.80 & -1290086 & 952951 \\
\hline $\begin{array}{l}\text { Cumulative } \\
\text { non-operating accruals }\end{array}$ & 720 & -14726.51 & 1357.50 & 283987.4 & -4300551 & 2249803 \\
\hline Firm's abnormal returns & 720 & 0.279 & -62.515 & 149.90 & -119.75 & 847.19 \\
\hline Loss reversal probability & 720 & 0.111 & 0.102 & 0.151 & -0.701 & 0.628 \\
\hline $\begin{array}{l}\text { Earnings per share of the } \\
\text { stock price }\end{array}$ & 720 & 0.052 & 0.092 & 2.053 & -43.185 & 20.046 \\
\hline
\end{tabular}

8.1 Descriptive Statistics

Table 1. Descriptive statistics of variables

Descriptive findings of this study include average, median, standard deviation, minimum observed and maximum observed which are presented in the following tables. It should be noted that 72 firms are studied, and their data are collected for 10 consecutive years. 
As it can be seen in the above table, the average of net profit in the sample firms is equal to 22,582 million Rials, and their average return is equal to 72.71 percent. This issue suggests that even though sample firms achieved profit after loss, in average in this period they had relatively good economic status. Standard deviation of the net profit is 144478 , and standard deviation of sample firms' return is 150.46 , which means wide income distribution of benefit and loss, and their achieved return in the period of investigation. This is of course evident due to the selection criteria and the research population because we have been looking for the firms in which loss reversal is obvious, in other words, they reached profit from loss. The mean value of 2.461 for the ratio of market value to book value also emphasizes on this subject, which alongside factors such as an increase in asset value due to inflation, which is out of the company's operating activities, their conversion of loss to the benefit, has incrementally improved this ratio. Average sum of accruals being negative is due to average net income being lower than the average of net cash flow from operating activities. It can be seen that in this table, similar to the variables of previous model (conservative model) the standard deviation of variables is very high. It is natural that this is due to changes in the performance of the company and the negative income becomes positive. Another thing that is important in the above table is that the average net cash flow from investing activities was negative in the sample companies. This is in line with hypothesis number two, because high level of investment cash flows and more importantly, these cash flows being negative and output, can prove this hypothesis to some extent.

\subsection{Data Analysis and Hypotheses Testing}

\subsubsection{Fitting the Degree of Conservatism Measurement Model (C-Score Model)}

The purpose of this study is initially identification of the variables associated with loss reversal consistent with the conditions prevailing in the Tehran Stock Exchange. For this purpose, the model proposed by Joos and Plesko (2005) is applied. In this model, the degree of conservatism of the company has been expressed as an independent variable. According to the models discussed in Chapter III to calculate the degree of conservatism in this study to calculate this variable, Khan and Watts Model (2007) was used as follows:

$$
\begin{aligned}
& X_{i t}=\beta_{0}+\beta_{1} D_{i t}+R_{i t}\left(\alpha_{0}+\alpha_{1} \text { Size }_{i t}+\alpha_{2} M / B_{i t}+\alpha_{3} \text { Lev }_{i t}\right) \\
& +D_{i t} R_{i t}\left(\gamma_{0}+\gamma_{1} \text { Size }_{i t}+\gamma_{2} M / B_{i t}+\gamma_{3} \text { Lev }_{i t}\right)+\varepsilon_{i t}
\end{aligned}
$$

In the above model: $X_{i t}$ Represents net profit, $D_{i t}$ is a dummy variable that if the firm's returns is positive it is equal to one, and otherwise it is equal to zero, $R_{i r}$ represents the efficiency of the company, $M / B_{i t}$ is the ratio of market value to book value of the company and $\operatorname{Lev}_{\text {it }}$ reflects the financial leverage of the company. For the calculation of the degree of conservatism, the above model is first fitted, and after determining regression coefficients, the degree of conservatism is calculated from the following equation:

$$
C_{-} \text {Score }_{i t}=\gamma_{0}+\gamma_{1} \text { Size }_{i t}+\gamma_{2} M / B_{i t}+\gamma_{3} \text { Lev }_{i t}
$$

Since the above model is a hybrid one, to identify the type of method used for estimation it is necessary to applied F-Limer test (Chow) is to the model. The results of this test to calculate the degree of conservatism is as follows.

Table 2. Results of F-limer test (chow) to the C-score model

\begin{tabular}{llll}
\hline Hypothesis $\mathbf{H}_{\mathbf{0}}$ & F statistics & P-Value & Test result \\
\hline $\begin{array}{l}\text { Simple OLS model preference } \\
\text { Rhjan model OLS Applying the time }\end{array}$ & 1.327 & 0.043 & $\begin{array}{l}\text { Reject } \mathrm{H}_{0} \text { : The panel method is suitable } \\
\text { factor }\end{array}$ \\
\hline
\end{tabular}

According to the above table, the P-Value of the F-test in the first case is equal to 0.043, which indicates the rejection of $\mathrm{H}_{0}$ hypothesis, i.e. simple OLS method has no superiority over fixed effects panel method. In the latter case, the P-Value of F-test is equal to 0.068 , which indicates that the hypothesis $\mathrm{H}_{0}$ is acceptable, and the result is the superiority of OLS method with applying time factor in fixed effects panel method. Considering the results of the $\mathrm{F}$ test and the acceptance of OLS method with applying the time factor for fitting conservative model, it is necessary to first examine the assumptions underlying regression analysis in order to avoid any cross fit. For this purpose, we first attempt to evaluate the autocorrelation between the error terms. The results of this test are as follows. 
Table 3. Correlation test results for the $\mathrm{C}$-score

\begin{tabular}{llll}
\hline Hypothesis $\mathbf{H}_{\mathbf{0}}$ & Durbin-Watson statistic & P-Value & Test result \\
\hline The absence of autocorrelation & 1.498 & $<0.001$ & Reject the hypothesis $\mathrm{H}_{0}$ \\
\hline
\end{tabular}

Due to the lack of confirmation of the above infrastructure assumption, and the existence of autocorrelation between residues of the fit model based on these test results, we can conclude that we are not permitted to use the OLS method with applying time to fit the conservative model. To resolve this problem, the method of generalized least squares (GLS) will be used. The results of estimating the model are summarized in the following Table.

Table 4. Results of model C-score

\begin{tabular}{|c|c|c|c|c|}
\hline Variables & Regression coefficients & Standard deviation & T-statistics & P-Value \\
\hline Constant $\beta_{0}$ & 0.158 & 0.257 & 0.614 & 0.539 \\
\hline $\mathrm{D}_{\mathrm{it}}$ & 0.085 & 0.172 & 0.495 & 0.621 \\
\hline $\mathrm{R}_{\mathrm{it}}$ & 0.009 & 0.172 & 1.854 & 0.047 \\
\hline $\mathrm{R}_{\mathrm{it}}{ }^{*}$ Size $_{\mathrm{it}}$ & -0.0003 & 0.013 & -0.025 & 0.979 \\
\hline $\mathrm{R}_{\mathrm{ir}}{ }^{*} \mathrm{M} / \mathrm{B}_{\mathrm{it}}$ & -0.0002 & 0.001 & -0.132 & 0.895 \\
\hline $\mathrm{R}_{\mathrm{it}}{ }^{*} \mathrm{LEV}_{\mathrm{it}}$ & 0.001 & 0.003 & 0.497 & 0.619 \\
\hline $\mathrm{R}_{\mathrm{it}}^{*} \mathrm{D}_{\mathrm{it}}$ & -0.024 & 0.211 & -2.104 & $0.030^{*}$ \\
\hline $\mathrm{R}_{\mathrm{it}}{ }^{*} \mathrm{D}_{\mathrm{it}}{ }^{*}$ Size $_{\mathrm{it}}$ & 0.0016 & 0.232 & -2.183 & $0.038^{*}$ \\
\hline $\mathrm{R}_{\mathrm{it}}{ }^{*} \mathrm{D}_{\mathrm{it}}{ }^{*} \mathrm{M} / \mathrm{B}_{\mathrm{it}}$ & 0.0002 & 0.107 & 1.972 & $0.048^{*}$ \\
\hline $\mathrm{R}_{\mathrm{it}}{ }^{*} \mathrm{D}_{\mathrm{it}}{ }^{*} \mathrm{LEV}_{\mathrm{it}}$ & -0.0017 & 0.0031 & -0.548 & 0.584 \\
\hline
\end{tabular}

Significance level ( $\alpha$ error): 0.001 for "***", 0.01 for "**", 0.05 to "*" and 0.1 for "+"

The estimated model is: $X_{i t}=0.158+0.085 D_{i t}+R_{i t}\left(0.009-0.0003\right.$ Size $_{i t}-0.0002 \mathrm{M} / B_{i t}+0.001$ Lev $\left._{i t}\right)$ $+D_{i t} R_{i t}\left(-0.024+0.0016\right.$ Size $_{i t}+0.0002 M / B_{i t}-0.0017$ Lev $\left._{i t}\right)+\varepsilon_{i t}$

According to Table 4 described above, a significant coefficient of t-statistic indicates the significance of the variables used in the equation of calculating C-Score, except Rit* Dit * LEVit variable which is in fact the same degree of financial leverage in the final equation. Therefore, the model for calculating the degree of conservatism can be expressed as follows:

$$
C_{-} \text {Score }_{i t}=-0.02453+0.0016 \text { Size }_{i t}+0.00024 \mathrm{M} / B_{i t}+0.00173 \text { Lev }_{i t}
$$

According to the above equation, the conservatism coefficient was calculated for each year-company and in conjunction with other variables was used for fitting the loss reversal probability model.

\subsubsection{Fitting the Loss Reversal Probability Model}

Testing the first to the third hypotheses of this study is dependent to the goodness of fit of the loss reversal probability model. Loss reversal probability model is a logit model and is expressed as probability. Logit models represent the models that their dependent variable is binary. In a logit model, logarithmic odds are modeled as output of the model and are based on a combination of independent variables. Therefore, we cannot use ordinary regressions (where dependent variable should be quantitative) in these models to predict the occurrence of the dependent variable. In this type of regression, the odds ratio, which is the ratio of success to failure, is used. It should be noted that in logit model there is no linear regression preconditions such as a linear relationship between the dependent and independent variables, homoscedasticity of dependent and independent variables, normal distribution of dependent variables and residuals, or measurement errors. Given that the loss reversal model is of synthetic data, it is necessary to find the appropriate estimation type for it using Akaike Information Criterion (AIC). For this purpose we estimate loss reversal logit model using four methods including simple GLM, time series GLM method (only by considering time), panel method with fixed effects and panel model with variable effects, and will compare their AIC. Each of the models that have a smaller AIC will be used as the favorite and ultimate model. Final results from the fit of the four models and AIC values for each are as follows. 
Table 5. Results of AIC statistics for loss reversal

\begin{tabular}{lllllll}
\hline $\begin{array}{l}\text { Identification } \\
\text { criteria }\end{array}$ & $\begin{array}{l}\text { Simple } \\
\text { GLM } \\
\text { model }\end{array}$ & $\begin{array}{l}\text { GLM model with } \\
\text { applying the } \\
\text { factor }\end{array}$ & $\begin{array}{l}\text { Generalized } \\
\text { model with } \\
\text { effects }\end{array}$ & $\begin{array}{l}\text { panel } \\
\text { fixed }\end{array}$ & $\begin{array}{l}\text { Generalized } \\
\text { model with } \\
\text { effects }\end{array}$ & $\begin{array}{c}\text { panel } \\
\text { variable }\end{array}$ \\
\hline AIC factor & 261.67 & 236.31 & 263.67 & 263.67 \\
\hline
\end{tabular}

According to the above table and AIC values for each of the four models, it can be concluded that the GLM model with applying time effects due to its minimum AIC value is the best method for fitting the loss reversal model. The results of the loss reversal final model are given in the following Table.

Table 6. The results of the loss reversal model

\begin{tabular}{|c|c|c|c|c|c|}
\hline Variables & Symbol & $\begin{array}{l}\text { Regression } \\
\text { coefficients }\end{array}$ & $\begin{array}{l}\text { Standard } \\
\text { deviation }\end{array}$ & T-statistics & P-Value \\
\hline Constant & $\alpha_{0}$ & 0.1613 & 0.138 & 1.163 & 0.245 \\
\hline Total accruals & $\mathrm{ACC}$ & 0.5318 & 0.102 & 5.175 & $<0.001 * * *$ \\
\hline $\begin{array}{l}\text { Three-year average of total } \\
\text { accruals }\end{array}$ & PACC & -1.1638 & 0.138 & -8.411 & $<0.001 * * *$ \\
\hline $\begin{array}{l}\text { Net cash flow of operating } \\
\text { activities }\end{array}$ & $\mathrm{CFO}$ & 0.4755 & 0.135 & 3.522 & $0.0004 * * *$ \\
\hline $\begin{array}{l}\text { Three-year average net } \\
\text { operating cash flow }\end{array}$ & PCFO & -1.2031 & 0.173 & -6.930 & $<0.001 * * *$ \\
\hline Sales growth & SG & 0.0023 & 0.002 & 1.058 & 0.290 \\
\hline Company Size & Size & -0.0046 & 0.010 & 0.426 & 0.670 \\
\hline The first year of the loss. & FirstLoss & 0.1077 & 0.045 & 2.389 & $0.017^{*}$ \\
\hline Pay dividends in loss & DIV & -0.4714 & 0.310 & -1.518 & 0.129 \\
\hline $\begin{array}{l}\text { Non-payment of dividends in } \\
\text { loss }\end{array}$ & DivStop & -0.2634 & 0.040 & -6.435 & $<0.001 * * *$ \\
\hline Income Tax & ITE & 0.2767 & 0.213 & 1.303 & 0.192 \\
\hline Specific costs investment & EXRD & -0.0503 & 0.229 & -0.219 & 0.826 \\
\hline $\begin{array}{l}\text { Net cash flow of investing } \\
\text { activities }\end{array}$ & $\mathrm{CI}$ & 0.2301 & 0.106 & 2.164 & $0.030^{*}$ \\
\hline Degree of conservatism & C-Score & -0.2471 & 0.040 & -6.127 & $<0.001 * * *$ \\
\hline $\begin{array}{l}\text { Cumulative non-operating } \\
\text { accruals }\end{array}$ & CNOACC & 0.0497 & 0.052 & 0.955 & 0.340 \\
\hline
\end{tabular}

Significance level (error $\alpha$ ): 0.001 for "***", 0.01 for "**", 0.05 for "*" And the 0.1 for "+"

$$
\log \left(\frac{P\left(Y_{i, t+1}=1\right)}{1-P\left(Y_{i, t+1}=1\right)}\right)=0.1613+0.531 A C C_{i, t}-1.163 P A C C_{i, t}+0.475 C F O_{i, t}-1.203 P_{C F O}, t
$$

The estimated model is: $+0.002 S G_{i, t}-0.004$ Size $_{i, t}+0.107$ FirstLoss $_{i, t}-0.471$ DIV $_{i, t}-0.263$ DivStop $_{i, t}$

$$
+0.277 \text { ITE }_{i, t}-0.05 \text { EXRD }_{i, t}+0.23 \text { CI }_{i, t}-0.247 C_{-} \text {Score }_{i, t}+0.049 \text { CNOACC }_{i, t}+\varepsilon
$$

As is clear from the results of the Table 6, according to the t-statistic in coefficient significance and regression signs of each variables, it can be concluded that the total accruals, net cash flow from operating activities, net cash flows from the investment activities and the first year of loss variables have significant positive correlation with loss reversal probability in the coming year. Also, three-year mean values of total accruals as well as three-year average of net cash flows from operating activities, non-payment of dividends in loss year and the degree of firm's conservatism have a significant negative relationship with the possibility of loss reversal in the following year. Meanwhile, sales growth, firm size, profit payments in loss year, income tax, investment in specific costs, and non-operating accumulated accruals variable have no significant relationship with loss reversal in the following year. Considering the loss reversal probability in final equation above, the probability of becoming profitable related to each year-firm of the sample firms in the following year was calculated, in 
order to be used along with other control variables to fit the model of relationship between loss reversal and abnormal returns.

\subsubsection{Fitting the Model of Relationship between the Loss Reversal and Abnormal Returns}

After calculating the loss reversal probability, they can be used to assess the relationship between companies become profitable in the following year after loss with abnormal returns. For this purpose, a model adapted from Jiang (2013) study was used. Since the model is a regression model with synthetic data, for its proper estimation it is necessary to perform F-Limer test on it. The results of this test are as follows.

Table 7. The results of F-limer test for the relationship between loss reversal and stock abnormal returns

\begin{tabular}{llll}
\hline Hypothesis $\mathbf{H}_{\mathbf{0}}$ & F statistics & P-Value & Test result \\
\hline Simple OLS model preference & 18.097 & $<0.001$ & Reject $\mathrm{H}_{0}$ panel method is better \\
OLS Time series model preferences & 20.524 & $<0.001$ & Reject $\mathrm{H}_{0}$ panel method is better \\
\hline
\end{tabular}

The results of the F-limer test for analysis model of relation between loss reversal and abnormal stock returns suggests that the data in this model follows the panel method. Once using panel data is confirmed, it is necessary to specify whether the panel model should have fixed effects or random effects. For this purpose, we used Hausman test, and the results are summarized in the following Table.

Table 8. The results of the Hausman test for the model of relationship between loss reversal and abnormal returns

\begin{tabular}{lllll}
\hline \multicolumn{1}{l}{ Hypothesis $\mathbf{H}_{\mathbf{0}}$} & & $\begin{array}{l}\text { Chi-square } \\
\text { statistics }\end{array}$ & P-Value & Test result \\
\hline $\begin{array}{l}\text { Using random } \\
\text { method }\end{array}$ & effects & 13.727 & 0.132 & $\begin{array}{l}\text { Accept } \mathrm{H}_{0} \text { panel method with random effects is } \\
\text { better }\end{array}$ \\
\hline
\end{tabular}

Due to the acceptance of the null hypothesis of Hausman test for the above model, we conclude that panel method with random effects is the right method for estimating parameters of the model.

Before fitting the random effects panel method, we need to check whether we can combine the time and location factors in this or not. To prove this, we use the Lagrange multiplier (LM) test in Pagan method, results of which are summarized in the following Table.

Table 9. Test results of integration capabilities for the model of relationship between loss reversal and abnormal returns

\begin{tabular}{lllll}
\hline Hypothesis $\mathbf{H}_{\mathbf{0}}$ & $\begin{array}{l}\text { Chi-square } \\
\text { statistics }\end{array}$ & P-Value & Test result \\
\hline $\begin{array}{l}\text { Combining of location is } \\
\text { possible }\end{array}$ & 1091.317 & $<0.001$ & $\begin{array}{l}\text { Reject the hypothesis } \mathrm{H}_{0:} \text { There is no place } \\
\text { integration capabilities }\end{array}$ \\
$\begin{array}{l}\text { Combining of time is possible } \\
\begin{array}{l}\text { Combining of time and location } \\
\text { simultaneously is possible }\end{array}\end{array} 1.813$ & 0.178 & $\begin{array}{l}\text { Accepting the hypothesis } \mathrm{H}_{0:} \text { There is a time } \\
\text { integration capabilities }\end{array}$ \\
\hline
\end{tabular}

According to the above table and with respect to Chi-square statistics valuesobtained by Lagrange multiplier test using Pagan method, it can be concluded that time factor combination method is suitable for fitting the model of relationship between the loss reversal and abnormal returns. The most important requirement in the use of combined panel models is the lack of autocorrelation between the error terms. To check this condition in the model analysis of the relationship between loss reversal and abnormal stock return, Breusch-Godfrey test was used in this study. The results of this test on the interfering components of the model resulted from $\mathrm{R}$ software is described for in the following Table. 
Table 10. Breusch -Godfrey test results for the model of relationship between loss reversal and abnormal returns

\begin{tabular}{llll}
\hline Hypothesis $\mathbf{H}_{\mathbf{0}}$ & $\begin{array}{l}\text { Chi-square } \\
\text { statistics }\end{array}$ & P-Value & Test result \\
\hline $\begin{array}{l}\text { The lack of correlation } \\
\text { between the error terms }\end{array}$ & 392.296 & $<0.001$ & $\begin{array}{l}\text { Reject the hypothesis } \mathrm{H}_{0:} \text { The existence of } \\
\text { correlation between the error terms of the model }\end{array}$ \\
\hline
\end{tabular}

Since the P-Value of Breusch -Godfrey test is less than 0.001, therefor the null hypothesis of the test, which is inexistence of autocorrelation among the interfering components of the model will be rejected, and as the result, the error terms of the model have a serial autocorrelation. The existence of autocorrelation between the residues of the model would cause bias in the estimation of the model. To solve this problem and to better estimate the model parameters, we use the panel-generalized method (PGLM) for final fitting of the model. As mentioned earlier, Generalized Linear Models do not need any infrastructure assumptions of conventional models (least square error and so on). The results of estimating parameters of this model are the presented in the following Table.

Table 11. Results of the final fitting the model of analysis of the relationship between loss reversal and abnormal returns

\begin{tabular}{|c|c|c|c|c|c|}
\hline Variables & Symbol & $\begin{array}{l}\text { Regression } \\
\text { coefficients }\end{array}$ & $\begin{array}{l}\text { Standard } \\
\text { deviation }\end{array}$ & T-statistics & P-Value \\
\hline Constant & $\mathrm{b}_{0}$ & -4.892 & 8.428 & -5.804 & $<0.001 * * *$ \\
\hline Loss reversal probability & LossRev & 5.956 & 2.115 & 2.816 & $0.005 * *$ \\
\hline Company Size & Size & 3.720 & 6.792 & 5.476 & $<0.001 * * *$ \\
\hline $\begin{array}{l}\text { The ratio of market value to } \\
\text { book value }\end{array}$ & MB & -3.104 & 1.411 & -2.198 & $0.027 *$ \\
\hline Earnings Per Share & EP & 5.512 & 2.452 & 2.247 & $0.024 *$ \\
\hline Dividends payable & DY & 5.534 & 2.019 & 2.471 & $0.006^{* *}$ \\
\hline Investment in Specific costs & $\mathrm{RD}$ & 4.270 & 8.299 & 0.514 & 0.606 \\
\hline $\begin{array}{l}\text { Net cash flow of operating } \\
\text { activities }\end{array}$ & $\mathrm{CF}$ & 4.290 & 2.379 & 0.180 & 0.856 \\
\hline Financial leverage of the firm & Lev & -8.519 & 4.565 & -1.866 & $0.062 *$ \\
\hline Stock price & $\mathrm{P}$ & 9.393 & 1.004 & 9.350 & $<0.001 * * *$ \\
\hline
\end{tabular}

Significance level ( $\alpha$ error value): 0.001 to "***", 0.01 for the "**", $0: 05$ to "*" and the 0.1 for the "+"

The estimated model is: MAdjRET $_{i, t+1}=-4.892+5.956 \operatorname{Loss~Rev}_{i, t}+3.720$ Size $_{i, t}-3.104 M B_{i, t}+5.512 E P$

$$
+5.534 D Y_{i, t}+4.270 R D_{i, t}+4.290 C F_{i, t}-8.519 L E V_{i, t}+9.393 P_{i, t}+v_{i, t+1}
$$

As is clear from the results of the Table 11, according to the t-statistic in coefficient significance and regression signs of each variables, it can be concluded that loss reversal probability, firm size, earnings per share, and share price variables have significant positive correlation with the firms' abnormal return. Also, the ratio of market value to book value and financial advantage of the firm (in 90 percent error level) have significant negative relationship with stock's abnormal return. In this model, two variables of specific investment costs and the net cash flow from operating activities have no significant relationship with stock's abnormal returns.

\section{Research Findings}

\subsection{First Hypothesis}

The variable of Investment in Specific costs and the probability of the loss making firms become profitable in the following year (Hypothesis number one) have a p-value of $0 / 826$ and $t$ statistic of -0.219 , therefore the hypothesis $\mathrm{H} 0$ is accepted. Hence, no significant relationship was observed between the level of investment in specific costs in loss making companies listed in Tehran Stock Exchange and loss reversal in the following year. 


\subsection{The Second Hypothesis}

In this hypothesis, we considered the relation between the level of investment in capital assets in loss making companies, and the by the amount of 0.030 as the p-value obtained from the fitting of the model, and by regression coefficient of 0.2301 for this variable, the corresponding $\mathrm{H} 0$ hypothesis was rejected. Therefore, it can be argued that in $95 \%$ significance level (5\% error level), the variable of investment in capital assets has positive and significant relationship with the probability of loss reversal. Therefore, the second hypothesis of this study that is the existence of a significant positive correlation between investment in capital assets and the possibility of loss reversal will be accepted.

\subsection{The Third Hypothesis}

The third hypothesis of this study is to describe a significant negative correlation between the level of conservatism and the possibility of loss reversal in the following year, which is accepted in 99 percent level according to regression coefficients, p-value and the t-statistic, equal to $-0.247,<0.001$ and- 6.127 , respectively. It should be noted that in the third hypothesis of this study, since accounting conservatism is an indicator of stability of financial reporting, thus reducing the impact of conservatism is considered on future profits that are expected to continue for at least a short period of time. This means that companies with higher level of conservatism are more likely to experience a continued loss, in other words, accounting conservatism practices either accelerates the identification of future losses or delays identification of current profits.

\subsection{Fourth Hypothesis}

The main objective of this study was to investigate the fourth hypothesis regarding the presence or absence of the relationship between loss reversal probability and abnormal returns in the future, which represents the probability of the stock price becoming profitable. Considering the result of the final model estimation for this hypothesis, p-value and the corresponding regression coefficient are equal to 0.005 and 5.965 , respectively. Hence, this hypothesis is accepted at a significance level of 99 percent.

\section{Comparing the Results of Assumptions with Performed Investigations}

For the first hypothesis of this study, no significant relationship was observed in this study between the level of investment in specific costs and loss reversal, which is in contrast with previous researches including Joos and Plesko (2005) who observed a significant negative relationship for these two variables in the United States. In addition, Holthausen and Larcker (1992) have shown a significant relationship between specific costs and stock earnings. Lewis (2008) has pointed out through a study that there are inevitable evidences from United States and the Kingdom state indicating that investment in $\mathrm{R} \& \mathrm{D}$ expenditures are positively related to efficiency of operation and efficiency of the market. Settino and Strong (1998) established this relationship in a direct and significant way in the UK. D. Massey (2001) shows a high affinity between the two variables and suggests that high level of loss continuation has high affinity with this kind of resource consumption in specific assets, and highly changes with the investment policies of the firm. Further, inside the country, Pourheidari (2004) suggests specific costs (costs of advertising and marketing) to affect stock returns. The results of the second hypothesis of this study shows a significant positive correlation between the level of investment in capital assets and likeliness of the firm becoming profitable in the following year. The result of Pelsko and Joos (2005) research in the United States, Wu (2013) in Australia and Darrough and Ye (2007) are similarly repeated. Also in R Balakrishnan et al. (2007) using data from Australia, a significant relationship between these two variables was observed. In addition, in domestic researches, Bahar Moghaddam et al. (2012) and Jahankhany and Ghorbani (2005) showed that the companies' investments in fixed assets (net cash from investing activities) are significantly correlated with stock returns. On the third hypothesis of this study, it was proven that there is a significant negative relationship between conservatism accounting and loss reversal. In this regard, the relationship Feltham and Ohlson (1995) and Basu (1997) similarly argue that conservatism accounting would lead to longer loss experience. In addition, DeChow and Skinner (1994) argued that adopting conservatism accounting methods will cause incomes to be less stable, compared to the time when less conservatism is applied. On the other hand, Beaver and Ryan (2005) and Penman and Zhang (2000) examined positive earnings (profits) and negative (loss) behavior of conservatism accounting and found that the degree of firms' conservatism directly affect the stock income. Givoly and Hayn (2000) suggest in their study that the degree of accounting conservatism increases as the loss event increases over time. Similar to the results of these two studies, Balakrishnan et al. (2007) using data from Australia suggests that loss making firms are more conservative than profitable companies. Common point of all these three studies is that firms with higher level of conservatism are more likely to experience loss continuation. In other words, conservative accounting practices accelerate the identification of future losses or delaying the recognition of current profits. In Iran, Mohamadzadgan (2006), Ghaemi and others (2010) showed that profit stability in companies that report 
more benefits that are conservative is lower, and price-to-earnings ratio in companies that report more profits that are conservative is lower. Therefore, while they entice investors and analysts upon this point to make investment decisions, they also suggest that the standard setting bodies, consider the benefits and disadvantages of conservative accounting all together. In fourth hypothesis, we showed that there is a positive and significant relationship between the probability of loss making companies being profitable in future periods and abnormal stock returns. In this regard, Sin and Watts (2000) also evaluated loss-making companies in Australia and showed that investors of loss making companies that eventually become profitable treat losses as a volatile item, since the impact of loss reversal on stock prices is visible positively and significantly. In addition, Collins and Hirbar (2002) and Chen et al. (2011) and Joos and Plesko(2005) showed that the relationship between negative earnings and stock prices and performance is inverse, however, when there is a probability of loss reversal, return on equity will have incremental rate due to positive changes in the stock price. Dhaliwal et al. (2000) showed that the ratio of net losses for loss making companies in their investing model is significantly negative. Obviously, the result of it will be a significant negative correlation between the loss and the stock price. Among the studies performed in the country and based on Tehran Stock Exchange data, Pourheydari (2004) provides evidences concerning the relationship between the profitability of firms with negative earnings (loss) and expectations of investors. His research suggested a new relationship on the relationship between the ratio of market value to book value (MTB) and the ratio of earning to book value (ETB). The results indicate that if the accounting incomes are negative (loss), the two ratios are negatively and significantly correlated to each other. In addition, Baharmoqadm et al. (2012) shows a direct and significant relationship between the accounting income value and abnormal returns in Tehran Stock Exchange.

\section{Practical Suggestions}

1) During the study, regarding review of study literature and information resources related to the topic, results and achievements of the present study, the following recommendations are suggested to organization managers, investors and Tehran Stock Exchange:

2) First, regarding confirmation of a number of hypotheses of this study, of which some affecting variables on loss reversal are identified, investors are recommended to take into consideration these subjects.

3) Due to the fact that investors review the firm's financial information especially Income and loss statements, and hence informing them about the existing links among items of financial statements would be very helpful, therefore we recommend the use of the results of this study when they consider investing in loss making companies.

4) The findings of this research highlight the need for introducing a regulation in Stock Exchange about loss making firms. So the next step is to suggest to Stock Exchange policymakers to propose laws so that before firms leave stock exchange because of loss making, they attempt to predict the profitability of these companies and then take a decision whether it is necessary to remove them from the list.

\section{Further to the Study}

1) In future studies, instead of future abnormal returns, price changes can be directly examined.

2) This study took place in situations where much difficulty was faced in accessing information for all loss making firms, and as it was noted in limitations section, the sample size was affected. It is suggested that if there is access to firms' internal information or the data of Stock Exchange, which are not available to the public, the study with a bigger sample size be carried out.

3) In this research, the degree of conservatism is determined by using return and market value to book value method, in future studies it is advisable to use other methods presented in chapter three.

\section{Limitations of the Study}

In the process of conducting a scientific study, there are circumstances that are not under the control of the researcher. Among the limitations of the present research, the following subjects can be mentioned:

1) The main limitation of the current study is the lack of proper disclosure of some of the variables of this study by firms, including investing in specific costs in financial statements and notes as separate and distinct costs from other expenditures.

2) Since under the regulation of Tehran Stock Exchange, the firms will leave after 3 consecutive years of loss, many of the firm that are familiar with the nature of the study were removed from the sample population due to lack of access to their information after they left the stock exchange. 
3) Since the financial statements report historical values and these values have generally major difference with current values, they have limited this research. Another major limitation of this study was the access to a limited population, due to the requirement of output data.

4) In this research, the firms listed in Tehran Stock Exchange were studied; it is recommended that in future OTC companies become also investigated.

5) Since this research is conducted for the companies listed in Tehran Stock Exchange for the period of 2005 to 2010, therefore, users of the results should be prudent when generalizing these results to other companies and times.

\section{References}

Baharmoqadm, M., \& Abbaszadeh, S. (2012). Companies' Investments and the Relationship between Loses and Companies' Value in companies listed in Tehran Stock Exchange. Journal of Accounting, III(9), 35-54 .

Balakrishnan, K., Bartov, E., \& Faurel, L. (2010). Post loss/profit announcement drift. Journal of Accounting and Economics, 50, 20-41.

Ball, R., \& Brown, P. (1968). An Empirical Evaluation of Accounting Income Numbers. Journal of Accounting Research, 6, 159-178. http://dx.doi.org/10.2307/2490232

Basu, S. (1997). The Conservatism Principle and the Asymmetric Timeliness of Earning. Journal of Accounting and Economic, 2, 3-28. http://dx.doi.org/10.1016/S0165-4101(97)00014-1

Basu, S. (1997). The conservatism principle and the asymmetric timeliness of earnings. Journal of Accounting and Economics, 24, 3-37.

Beaver, W. H., \& Ryan, S. G. (2005). Conditional and unconditional conservatism: Concepts and modelling. Review of Accounting Studies, 10(2-3), 269. http://dx.doi.org/10.1007/s11142-005-1532-6

Burgstahler, D., \& Dichev, I. (1997. Earnings, adaptation, and company value. The Accounting Review, 72, 187-215.

Chen, F., Hope, O., Li, Q., \& Wang, X. (2011). Financial reporting quality and investment efficiency of private firms in emerging markets. The Accounting Review, 86, 1255-1288. http://dx.doi.org/10.2308/accr-10040

Collins, D. W., \& Hribar, P. (2002). Errors in estimating accruals: Implications for empirical research. Journal of Accounting research, 40(1), 105-135. http://dx.doi.org/10.1111/1475-679X.00041

Darrough, M., \& Ye, J. (2007). Valuation of loss firms in a knowledge-based economy. Review of Accounting Studies, 12, 61-93.

Dechow, P. M., \& Skinner, D. J. (2000). Earnings management: Reconciling the views of accounting academics. practitioners, and regulators. Accounting Horizons, 14(2), 235-250. http://dx.doi.org/10.2308/acch.2000.14. 2.235

Dhaliwal, D. S., Kaplan, S. E., Laux, R., \& Weisbrod, E. (2012). The information content of tax expense for firms reporting losses. Journal of Accounting Research, 51(1), 135-164.

Fama, E. F., \& French, K. R. (1996). Multifactor explanations of asset pricing anomalies. Journal of Finance, 51, 55-84. http://dx.doi.org/10.1111/j.1540-6261.1996.tb05202.x

Fama, E. F., \& MacBeth, J. D. (1973). Risk, return, and equilibrium: Empirical tests. Journal of Political Economy, 81(3), 607-636. http://dx.doi.org/10.1086/260061

Feltham, G. A., \& Ohlson, J. A. (1995). Valuation and clean surplus accounting for operating and financial activities. Contemporary Accounting Research, 11(2), 689-731. http://dx.doi.org/10.1111/j.1911-3846.1995. tb00462.x

Garsia, L., Osma, B. G., \& Penalva, F. (2006). Cost of Equity and Accounting Conservatism. IESE Business School, University of Navara.

Ghaemi, M., \& Hajipour, M. (2010). The impact of conservatism on the stability of earnings and the price to profit ratio. Journal of Accounting, 1(2), 73-55.

Ghaemi, M., Masoumi, J., \& Azadi, M. (2011). Measurement of abnormal stock returns in a trading halt. Journal of Financial Accounting, III(3), 113-126.

Givoly, D., \& Hayn, C. (2000). The changing time-series properties of earnings, cash flows and accruals: Has financial reporting become more conservative? Journal of Accounting and Economics, 287-320. 
Givoly, D., Hayn, C. K., \& Natarajan, A. (2007). Measuring reporting conservatism. The Accounting Review, 82, 65-106.

Hayn, C. (1995). The information content of losses. Journal of Accounting and Economics, 20,125-154.

Heydari, O. P. (2004). Accounting losses and expectations of investors. Journal of Financial Research, 18, 27-39.

Holthausen, R., \& Larcker, D. (1992). The prediction of stock returns using financial statement information. Journal of Accounting and Economics, 15(2-3), 373-411. http://dx.doi.org/10.1016/0165-4101(92)90025-W

Jahankhany, A., \& Ghorbani, S. (2005). Identifying and explaining the determinants of dividend policy of the companies listed in Tehran Stock Exchange. Journal of Financial Research, 20, 25-45.

Jiang, W., \& Stark, A. W.,(2013). Dividends, research and development expenditures, and the value relevance of book value for UK loss-making firms. The British Accounting Review, 45(2), 112-124. http://dx.doi.org/ 10.1016/j.bar.2013.03.003

Joos, P., \& Plesko, G. A. (2005). Valuing loss firms. The Accounting Review, 80, 847-870.

Khan, M., \& Watts, R. L. (2009). Estimation and empirical properties of a firm-year measure of accounting conservatism. Journal of Accounting and Economics, 48, 132-150. http://dx.doi.org/10.1016/j.jacceco. 2009.08.002

Klein, A., \& Marquardt, C. (2006). Fundamentals of accounting losses. The Accounting Review, 81, 179-206.

Lewellen, J. (2010). Accounting anomalies and fundamental analysis: an alternative view. Journal of Accounting and Economics, 50(2\&3), 455-466.

Lewis, M. (2008). Islam and Accounting. Accounting Forum, 25(2), 103-127. http://dx.doi.org/10.1111/14676303.00058

Li, K. K. (2011). How well do investors understand loss persistence? Review of Accounting Studies, 16, 630-667.

Modigliani, F., \& Miller, M. H. (1966). Some estimates of the cost of capital to the electric utility industry (pp. 1954-1957). The American Economic Review, 56(3), 333-391.

Mohammad, A. Z. (2006). Evaluation of the reliability of accruals, earnings persistence and stock prices in firms listed in Tehran Stock Exchange. MS Thesis, International University of Imam Khomeini, Qazvin.

Ohlson, J. A. (1995). Earnings, book values and dividends in equity valuation. Contemporary Accounting Research, 11(2), 661-687. http://dx.doi.org/10.1111/j.1911-3846.1995.tb00461.x

Penman, S. H., \& Zhang, X. J. (2002). Accounting conservatism, the quality of earnings, and stock returns. The Accounting Review, 77(2), 237-264. http://dx.doi.org/10.2308/accr.2002.77.2.237

Richardson, S., Tuna, I., \& Wysocki, P. (2010). Accounting anomalies and fundamental analysis: A review of recent research advances. Journal of Accounting and Economics, 50(2-3), 410-454. http://dx.doi.org/10. 1016/j.jacceco.2010.09.008

Setiono, B., \& Strong, N. (1998). Predicting stock returns using financial statement information. Journal of Business Finance and Accounting, 25(5-6), 631-657. http://dx.doi.org/10.1111/1468-5957.00205

Sin, S., \& Watts, E. (2000). The information content of losses: Shareholder liquidation option and earnings reversals. Australian Journal of Management, 25, 327-338.

Wu, H., Fargher, N., \& Wright, S. (2010). Accounting for investments and the relevance of losses to firm value. International Journal of Accounting, 45, 104-127.

\section{Notes}

Note 1. The No-Effects Hypothesis.

Note 2. The Mechanistic Hypothesis.

\section{Copyrights}

Copyright for this article is retained by the author(s), with first publication rights granted to the journal.

This is an open-access article distributed under the terms and conditions of the Creative Commons Attribution license (http://creativecommons.org/licenses/by/3.0/). 